J. Clin. Chem. Clin. Biochem.

Vol. 27, 1989, pp. 13-18

(C) 1989 Walter de Gruyter \& Co.

Berlin - New York

\title{
Clinical Biochemistry of Sporidesmin Natural Intoxication (Facial Eczema) of Sheep
}

\author{
By M. Bonnefoi, J. P. Braun
}

Laboratoire Associé INRA de Toxicologie Biochimique et Métabolique, ENV, Toulouse, France

P. Bézille

Laboratoire de Pathologie du Bétail, ENV, Toulouse, France

J. LeBars

Station INRA de Pharmacologie et Toxicologie, Toulouse, France

G. Sawadogo

Laboratoire Associé INRA de Toxicologie Biochimique et Métabolique, ENV, Toulouse, France and

J. P. Thouvenot

Laboratoire de Biochimie II, Hopital Purpan, Toulouse, France

(Received June 21/October 10, 1988)

Summary: The effects of facial eczema, i.e. intoxication by the mycotoxin sporidesmin, were investigated by extensive biochemical screening of serum in 100 controls (A), 31 clinically ill (B) and 219 apparently healthy (C) Manech ewes under field conditions. Dramatic increases of $\gamma$-glutamyltransferase ${ }^{1}$ ), alkaline phosphatases, bilirubin, cholesterol, aspartate and alanine aminotransferases, and lactate dehydrogenase confirmed the severity of liver damage in group B, but they were also observed in slightly more than $50 \%$ of group C animals. This demonstrated the true extent of the disease, which could be best assessed by the measurement of serum $\gamma$-glutamyltransferase; but since this enzyme was still elevated one year later, it cannot be used as a reliable prognostic parameter.

\section{Introduction}

Facial eczema is a photosensitization syndrome secondary to liver damage by sporidesmins, the mycotoxins of Pithomyces chartarum. This disease, identi-

1) Ënzymes

Alanine aminotransferase ( $L$-Alanine: 2 -oxoglutarate aminotransferase, EC 2.6.1.2)

Alkaline phosphatase [Orthophosphoric-monoester phosphohydrolase (alkaline optimum), EC 3.1.3.1]

Aspartate aminotransferase ( $L$ =Aspartate:2-oxoglutarate aminotransferase, EC 2.6.1.1)

$\gamma$-Glutamyltransferase [(5-Glutamyl)-peptide : amino-acid 5glutamyltransferase, EC 2.3.2.2]

Lactate dehydrogenase (L-Lactate: $\mathrm{NAD}^{+}$oxidoreductase, EC 1.1.1.27) fied in Australia, New Zealand and South Africa (1), was first observed in European sheep in 1982 (2) and can be considered an interesting model for so-called hepatogenic photosensitization. Moreover, it was shown that in cattle herds in which less than $10 \%$ of animals exhibited the skin symptoms of the disease, 40 to $50 \%$ had elevated serum $\gamma$-glutamyltransferase indicative of severe liver disorders (3).

In sheep, the clinical biochemistry of facial eczema has almost only been investigated in experimental trials. To the best of our knowledge, there is only one report (4) of a spontaneous intoxication of 31 sheep out of a flock of 214, in which significant increases 
of serum cholesterol and aspartate aminotransferase were reported in most animals, while bilirubin was increased in about $50 \%$, and alkaline phosphatases and alanine aminotransferase were unchanged. Experimental studies following oral dosage with sporidesmin confirmed:

1) cholestasis with increases of bilirubin, cholesterol, triacylglycerols, phospholipids, bile acids and $\gamma$-glutamyltransferase $(5-8)$,

2) cytolysis with elevations of aspartate aminotransferase, ornithine carbamoyltransferase and glutamate dehydrogenase $(5,6,9)$,

3) liver function impairment with decrease of albumin and increases of prothrombin time and bromosulphonphthaleine retention $(6,10)$,

4) hepatitis with elevation of total proteins, mainly due to $\gamma$-globulins and to a lesser degree $\beta$-globulins $(6,10)$; moreover, alkaline phosphatases and alanine aminotransferase were shown to be unchanged $(5,6$, 9).

Nevertheless, as no study dealt with the comparison of the diagnostic value of these tests or with their applicability in field conditions, we devised an experiment to test the value of a wide panel of biochemical analyses on a large number of animals during an outbreak of the disease in 1984-85.

\section{Materials and Methods}

All observations were carried out in the French Pays Basque in Manech sheep between the autumn of 1984 and the autumn of 1985 . Facial eczema was assessed by clinical symptoms and the isolation and culture of the Pithomyces chartarum collected on the pastures (11), followed by identification and measurement of sporidesmin by high-performance liquid chromatography, as previously described $(12,13)$.

Serum biochemical profiles were analysed in the following ewes, all of which had been bred under almost the same conditions: 100 controls (group A) grazing pastures where no facial eczema or $P$. chartarum were recorded, 30 clinically ill cases of "facial eczema" with skin symptoms (group B), and 219 apparently healthy ewes (group C) grazing the same pastures as group B. Sodium, potassium, chloride, bicarbonates, calcium, phosphates, iron, urea, creatinine, urates, bilirubin, cholesterol, triacylglycerols, glucose, total proteins, albumin, alkaline phosphatases (EC 3.1.3.1), alanine aminotransferase (EC 2.6.1.1), aspartate aminotransferase (EC 2.6.1.2), lactate dehydrogenase (EC 1.1.1.27), and $\gamma$-glutamyltransferase (EC 2.3.2.2) were determined on a SMAC-Technicon AutoAnalyzer ${ }^{3}$ according to the designer's recommended procedures (14).

Moreover, the evolution of serum biochemistry with time was observed: a) for 200 days in 5 animals out of 25 in a flock (the other ones died spontaneously or were slaughtered), b) in 12 animals which had survived the disease and were sampled one year later.

Statistical calculations were performed by use of variance analysis, non parametric Mann-Whithney's and Wilcoxon's tests (15).

\section{Results}

No statistically significant variations were observed for sodium, potassium, bicarbonates, phosphates or urea, for which mean values and ranges calculated on the overall animals were 146 (125 to 156 ), 5.5 (4.0 to 13.3), 26 (16 to 31), 1.95 (1.07 to 3.14) and 6.59 (2.40 to 18.90$) \mathrm{mmol} / \mathrm{l}$, respectively. All other serum biochemical parameters were significantly disturbed in clinically ill, as well as in most of the apparently healthy animals. However, many results were characterized by a very large scatter.

\section{Clinically ill animals (group B)}

In animals of group B, with clinical symptoms of facial eczema, most changes were very intense, especially those of cholesterol, bilirubin, aspartate aminotransferase, alkaline phosphatases, lactate dehydrogenase, and $\gamma$-glutamyltransferase, which were increased more than 3 -fold. In comparison, calcium, iron, creatinine, triacylglycerols, total proteins and alanine aminotransferase were only slightly increased, whereas chloride, glucose and albumin were decreased (tab. 1).

\section{Apparently healthy animals (group C)}

In apparently healthy animals grazing the same pastures as group B, similar but less intense statistically significant disturbances were observed for the same parameters, except for chloride, proteins, glucose and alanine aminotransferase (values not shown). However, these animals formed a very heterogeneous group, with very broad ranges for most parameters, especially $\gamma$-glutamyltransferase. As shown in figure 1 , group $\mathrm{C}$ was clearly divided, according to the distribution of serum $\gamma$-glutamyltransferase activities, into two very different sub-groups: a relatively homogenous one having low activities and a very heterogenous one with high activities. Thus, subdivision of group $\mathrm{C}$ appeared necessary.

In seeking the best criterion for partition, the upper limit of "normal" was first determined for all the parameters showing significant changes in group B. The $m+3 \mathrm{~s}$ limits or the 99.5 percentiles of controls (group A) were chosen according to the Gaussian or non-Gaussian distribution of the parameters. The percentage of animals in group $\mathrm{C}$ which had values higher than these limits were then calculated. As shown in table 2, serum $\gamma$-glutamyltransferase provided the best results with a limit fixed at $112 \mathrm{U} / 1$ (i.e. $\mathrm{m}+3 \mathrm{~s}$ of values in controls, the distribution of which being not significantly different from Gaussian); no other test significantly improved the classification thus obtained. 
Tab. 1. Serum biochemistry in control sheep (group A), in sheep with clinical symptoms of facial eczema (group B) and in sheep grazing the same pastures as group B without clinical signs (group C) but having $\gamma$-glutamyltransferase values higher than the upper limit of controls ( $\gamma$-glutamyltransferase $>112 \mathrm{U} / 1$, see text). All values in group B are significantly different from controls $(p<0.01)$. All values in group $C$ with $\gamma$-glutamyltransferase $>112 \mathrm{U} / 1$ are significantly different from controls and from group $B(p<0.01)$, except where indicated.

a: not significantly different from group $B(p<0.01)$.

b: not significantly different from controls $(\mathrm{p}<0.01)$.

\begin{tabular}{|c|c|c|c|c|}
\hline & & $\begin{array}{l}\text { Group A } \\
\text { controls } \\
(n=100)\end{array}$ & $\begin{array}{l}\text { Group B } \\
\text { clinically-ill } \\
(\mathrm{n}=30)\end{array}$ & $\begin{array}{l}\text { Group } C \text { (apparently } \\
\left.\text { healthy) }+\mathrm{GGT}^{*}\right)>112 \mathrm{U} / 1 \\
(\mathrm{n}=114)\end{array}$ \\
\hline $\begin{array}{l}\text { Chloride } \\
\text { Calcium } \\
\text { Iron }\end{array}$ & $\begin{array}{l}\mathrm{mmol} / 1 \\
\mathrm{mmol} / 1 \\
\mu \mathrm{mol} / 1\end{array}$ & $\begin{array}{l}106(79 \text { to } 116) \\
2.56(2.05 \text { to } 2.88) \\
28(14 \text { to } 48)\end{array}$ & $\begin{array}{l}101(94 \text { to } 108) \\
2.71(2.44 \text { to } 3.02) \\
44(16 \text { to } 73)\end{array}$ & $\begin{array}{l}104(90 \text { to } 113) \\
2.69(2.05 \text { to } 3.28)^{\mathrm{a}} \\
38(10 \text { to } 67)^{\mathrm{a}}\end{array}$ \\
\hline $\begin{array}{l}\text { Creatinine } \\
\text { Bilirubin } \\
\text { Cholesterol } \\
\text { Triacylglycerols } \\
\text { Glucose } \\
\text { Albumin } \\
\text { Total proteins }\end{array}$ & $\begin{array}{l}\mu \mathrm{mol} / 1 \\
\mu \mathrm{mol} / 1 \\
\mathrm{mmol} / 1 \\
\mathrm{mmol} / 1 \\
\mathrm{mmol} / 1 \\
\mathrm{~g} / \mathrm{l} \\
\mathrm{g} / \mathrm{l}\end{array}$ & $\begin{array}{l}74(45 \text { to } 188) \\
2(0 \text { to } 4) \\
1.78(0.80 \text { to } 2.91) \\
0.20(0.02 \text { to } 0.70) \\
3.39(1.70 \text { to } 4.60) \\
34.3(27.9 \text { to } 42.8) \\
70(57 \text { to } 86)\end{array}$ & $\begin{array}{l}83(47 \text { to } 122) \\
22(2 \text { to } 93) \\
5.88(1.80 \text { to } 13.18) \\
0.45(0.14 \text { to } 1.02) \\
2.85(1.80 \text { to } 3.90) \\
30.6(24.8 \text { to } 46.6) \\
77 \text { (66 to } 91)\end{array}$ & $\begin{array}{l}84(53 \text { to } 135)^{a} \\
9(0 \text { to } 188) \\
3.25(1.30 \text { to } 11.70) \\
0.31(0 \text { to } 2.80) \\
3.64(1.06 \text { to } 6.40) \\
42.4(23.8 \text { to } 38.0) \\
73(54 \text { to } 88)\end{array}$ \\
\hline $\begin{array}{l}\text { Alkaline phosphatases } \\
\text { Alanine aminotransferase } \\
\text { Aspartate aminotransferase } \\
\text { Lactate dehydrogenase } \\
\gamma \text {-Glutamyltransferase }\end{array}$ & $\begin{array}{l}U / 1 \\
U / 1 \\
U / 1 \\
U / 1 \\
U / 1\end{array}$ & $\begin{array}{l}164(51 \text { to } 412) \\
16(3 \text { to } 75) \\
104(61 \text { to } 177) \\
557(370 \text { to } 1530) \\
72(28 \text { to } 111)\end{array}$ & $\begin{array}{l}936(220 \text { to } 3650) \\
28(1 \text { to } 87) \\
379(125 \text { to } 1470) \\
1763(752 \text { to } 3920) \\
1983(88 \text { to } 2565)\end{array}$ & $\begin{array}{l}687(58 \text { to } 3260) \\
21(0 \text { to } 184)^{b} \\
242(47 \text { to } 1175) \\
1376(130 \text { to } 3470) \\
1003(147 \text { to } 3624)\end{array}$ \\
\hline
\end{tabular}

*) GGT $=\gamma$-Glutamyltransferase

Tab. 2. Diagnostic value of the various serum parameters for facial eczema of sheep.

a: percentage of animals from group $\mathrm{C}$ having a given parameter higher than the upper limit $(\mathrm{N})$ of normal $(X>N)$.

b: percentage of animals from group $\mathrm{C}$ having a normal serum $\gamma$-glutamyltransferase activity and a given parameter higher than the upper limit $(N)$ of normal $(X>N$ and $\gamma$-glutamyltransferase $\leq 112 \mathrm{U} / \mathrm{l})$.

\begin{tabular}{|c|c|c|}
\hline & $\begin{array}{l}\text { a } \\
\text { Percent } \\
\text { of animals } \\
\text { with para- } \\
\text { meter > N }\end{array}$ & $\begin{array}{l}\mathrm{b} \\
\text { Percent } \\
\text { of animals } \\
\text { undetected } \\
\text { by GGT* } \\
\leq 112 \mathrm{U} / \mathrm{l}\end{array}$ \\
\hline$\gamma$-Glutamyltransferase & 53.92 & (not applicable) \\
\hline Alkaline phosphatases & 34.10 & 1.38 \\
\hline Lactate dehydrogenase & 30.77 & 1.54 \\
\hline $\begin{array}{l}\text { Aspartate } \\
\text { aminotransferase }\end{array}$ & 29.63 & 0.46 \\
\hline Cholesterol & 19.35 & 0.46 \\
\hline Bilirubin & 17.51 & 0 \\
\hline Iron & 10.50 & 0 \\
\hline Triacyglycerols & 7.83 & 0.46 \\
\hline $\begin{array}{l}\text { Alanine } \\
\text { aminotransferase }\end{array}$ & 4.63 & 0.93 \\
\hline Total proteins & 2.3 & 0.5 \\
\hline Albumin & 0.9 & 0.9 \\
\hline Creatinine & 0.9 & 0.5 \\
\hline Calcium & 0.5 & 0 \\
\hline Glucose & 0.5 & 0 \\
\hline Chloride & 0 & 0 \\
\hline
\end{tabular}

* GGT $=\gamma$-Glutamyltransferase
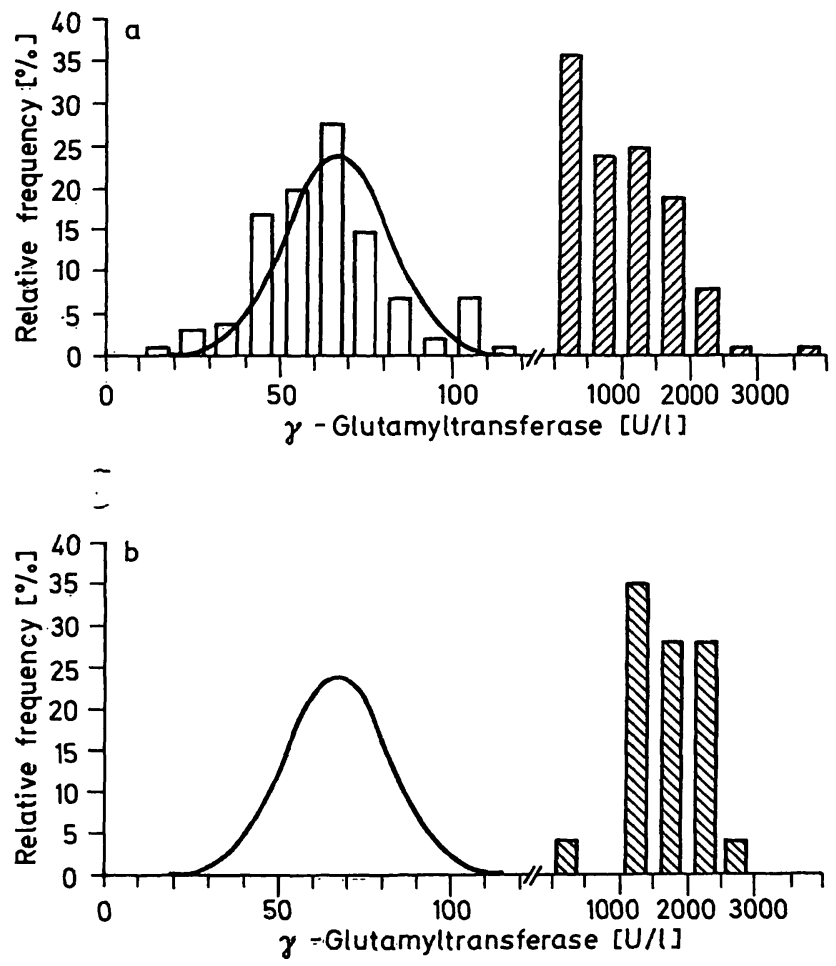

Fig. 1. Comparison of the distribution of serum $\gamma$-glutamyltransferase activity (given in $10 \mathrm{U} / \mathrm{l}$ and $500 \mathrm{U} / 1$ intervals) in (b) clinically ill (group $B, n=30$ ) and (a) apparently healthy (group $C, n=219$ ) sheep. The bellshaped line is the Gaussian distribution of serum $\gamma$ glutamyltransferase activity in controls (group $A$. $\mathrm{n}=100$ ). 


\section{Concise Encyclopedia Biochemistry}

\section{Second Edition,}

revised and expanded by Thomas Scott and Mary Eagleson

$1988.17 \mathrm{~cm} \times 24 \mathrm{~cm} .650$ pages. Hardcover. DM 148,-; approx. US $\$ 89.00$

ISBN 3110116251

The only single work of its kind in English, the Concise Encyclopedia of Biochemistry provides a comprehensive, yet compact, source of biochemical data and information for the researcher, teacher, and student.

Following a five-year program of collecting and editing new material, as well as the revision of existing entries, the author-editors and the publishers are pleased to announce the new expanded Second Edition of this valuable reference work.

Major entries concerning the latest developments in DNA structure, synthesis, sequencing, binding proteins and methods, oncogenes, lymphokines and other newly discovered regulatory peptides, structural proteins, inositol phosphates, and protein kinases have been added. Graphic illustration has been given high priority, so that regulatory processes, transport, subcellular structures, etc. are abundantly and clearly illustrated.

The coverage of plant biochemistry has also been greatly expanded. Another new addition is a section on buffers which will be useful to anyone involved in laboratory work. Because of its comprehensiveness and multidisciplinary nature, we are sure that you will find it an indispensable reference tool.

Special features of this edition include:

- Approximately 4,500 entries

- Up-to-date, comprehensive

- Coverage of medical, animal, microbial, plant, and physical biochemistry, natural products, molecular biology, molecular genetics, and biotechnology

- Hundreds of illustrations, including structural formulas, schemes, and metabolic pathways

O Over 100 tables

- Modern terminology based on standard sources, e. g., IUB Enzyme Nomenclature

- Standard biochemical abbreviations

- Extensive cross references with synonyms provided

- Literature references are cited to aid the reader in locating original sources

Potential audience: biochemists, clinical biochemists, clinical chemists, medical researchers, clinicians, plant scientists, experimental biologists, lecturers änd students of the life sciences. 
This result led to the subdivision of group $C$ into two sub-groups with $\gamma$-glutamyltransferase values above or below $112 \mathrm{U} / \mathrm{l}$. In the subgroup with $\gamma$-glutamyltransferase below $112 \mathrm{U} / \mathrm{l}(\mathrm{n}=105)$, no parameter showed significant differences from controls (group A), while in the sub-group with $\gamma$-glutamyltransferase higher than $112 \mathrm{U} / \mathrm{l}$, all parameters were significantly different from controls, except for alanine aminotransferase (tab. 1). However, in the latter animals most variations were significantly less intense than in clinically ill (group B) animals: only calcium, iron and creatinine showed similar (moderate) increases (tab. 1).

\section{Changes with time}

The changes in serum biochemistry in the five ewes observed for 200 days are given in table 3 for the only parameters showing significant alterations. At the beginning, biochemical disturbances were the same as in animals of group B, then chloride and glucose increased, while cholesterol, $\gamma$-glutamyltransferase and lactate dehydrogenase decreased. However, these recoveries were only significant at day 200 and at this date serum $\gamma$-glutamyltransferase $(p<0.001)$ and lactate dehydrogenase $(p<0.01)$ were still higher than in controls (group A). On day 200, $\gamma$-glutamyltransferase activities were above $112 \mathrm{U} / \mathrm{l}$, except in one animal.

In the 12 other animals, which had survived for one year, seven serum parameters were significantly ( $p>0.001)$ disturbed as compared to group A: potassium $(5.1 \mathrm{mmol} / \mathrm{l})$, bicarbonates $(23 \mathrm{mmol} / \mathrm{l})$, and glucose $(2.81 \mathrm{mmol} / \mathrm{l})$ were lowered, while cholesterol $(3.18 \mathrm{mmol} / \mathrm{l})$, total proteins $(80 \mathrm{~g} / \mathrm{l})$ and $\gamma$-glutamyltransferase $(186 \mathrm{U} / \mathrm{l})$ were increased.

\section{Discussion}

In clinically ill animals (group B), some of the intense disturbances observed had already been reported, following natural or experimental intoxications; they result from the postulated pathogenesis $(16,17)$ of sporidesmiotoxicosis:
- cholestasis and secondary cholangitis, with dramatic increases of $\gamma$-glutamyltransferase, alkaline phosphatase, bilirubin, cholesterol and more moderately of triacylglycerols,

- liver cytolysis demonstrated by increases of aspartate aminotransferase, alanine aminotransferase, lactate dehydrogenase and perhaps of iron,

- liver insufficiency shown by the decrease of albumin and glucose.

Nevertheless, in previous reports alkaline phosphatase and alanine aminotransferase were shown to be unchanged $(4,5,6,9)$ : this discrepancy could result from the lack of sensitivity of outdated analytical procedures and/or the relatively poor diagnostic significance of these enzymes in sheep (18) and/or individual variations.

Other disturbances, e.g. of calcium and chloride, could be the result of hydroelectrolytic changes in animals that remained prostrated and stopped feeding and drinking. The relatively moderate increases of creatinine could be result of kidney function impairement, as sporidesmin has also been reported to be nephrotoxic (19).

Serum biochemistry demonstrated that some apparently healthy animals of group $\mathrm{C}$ were suffering less intense but similar disturbances to those of the clinically ill group grazing the same pastures. This observation confirms that the disease is more widely distributed than would be supposed from the skin symptoms; this is already apparent from serum $\gamma$-glutamyltransferase measurement in cattle (3) and from the slaughter-house examination of sheep liver (21). However, group $\mathrm{C}$ was very heterogeneous and the most interesting observation is the diagnostic value of the concentration of $\gamma$-glutamyltransferase activity, which was the best parameter for revealing unapparent liver alterations in group $C$ animals. Serum $\gamma$ glutamyltransferase was previously demonstrated to be the best criterion for detecting liver lesions in experimental sporidesmiotoxicosis of sheep (8) and

Tab. 3. Changes in serum biochemistry with time in five sheep with facial eczema.

a: significantly different from day $40(p<0.01)$.

b: significantly different from day 60 ( $p<0.01)$.

\begin{tabular}{lllll} 
& & Day 40 & Day 60 & Day 200 \\
\hline Chloride & $\mathrm{mmol} / 1$ & $102(100$ to 104$)$ & $103(98$ to 106$)$ & $110(108 \text { to } 113)^{\mathrm{a} ; \mathrm{b}}$ \\
Glucose & $\mathrm{mmol} / \mathrm{l}$ & $3.26(2.70$ to 3.60$)$ & $3.52(3.00$ to 4.00$)$ & $4.50(4.20 \text { to } 4.90)^{\mathrm{a}}$ \\
Cholesterol & $\mathrm{mmol} / 1$ & $3.60(2.70$ to 4.40$)$ & $3.42(2.00$ to 4.40$)$ & $1.78(1.30 \text { to } 2.70)^{\mathrm{a}}$ \\
Lactate dehydrogenase & $\mathrm{U} / \mathrm{l}$ & $1527(1375$ to 1780$)$ & $1.655(890$ to 3470$)$ & $734(510 \text { to } 1095)^{\mathrm{a}}$ \\
$\gamma$-Glutamyltransferase & $\mathrm{U} / \mathrm{l}$ & $1807(1278$ to 2565$)$ & $1422(840$ to 2080$)$ & $469(110 \text { to } 1032)^{\mathrm{a}, \mathrm{b}}$ \\
\hline
\end{tabular}




\section{The Roots of Modlenm Biochemistry}

\section{Fritz Lipmann's Squiggle and its Consequences}

Editors Horst Kleinkauf, Hans von Döhren, Lothar Jaenicke

1988. $17 \mathrm{~cm} \times 24 \mathrm{~cm}$. XII, 988 pages. Numerous illustrations. Hardcover. DM 448,-; approx. US \$263.00 ISB̈N 3110115859

A Fritz Lipmann dedicatory volume, originating from the Memorial Meeting held in Berlin-Dahlem in 1987, presenting the major aspects of modern biochemistry and their development in 90 essays. The Warburg/Meyerhof era, the time of emigration and postwar science are revived. Contemporaries and coworkers together with other outstanding scientists describe the state of biochemistry in major fields: as it was, as it is now, and where it will be going. At the same time this volume is a reference book on Fritz Lipmann, the outstanding biochemist, and life scientist, who considered his concept of the energy-rich bond, symbolized by the squiggle, as his major achievement.

\section{From the Contents}

Fritz Lipmann 1899-1986 - Biochemistry Comes of Age · Molecular Biology Sharpens its Tools - Functional Dynamics: The Squiggle-Symbol of Bioenergetics; Molecular Recognition and Communication - Evolution - List of Contributors · Lipmann's Coworkers at Massachusetts General Hospital, Boston, and the Rockefeller University, New York · Fritz Lipmann: Bibliography 1924-1985 · Author Index · Subject Index 
natural facial eczema of cattle (20); in this experiment, it was demonstrated that it was also the best test in field conditions for sheep facial eczema.

As the sub-group with $\gamma$-glutamyltransferase below $112 \mathrm{U} / 1$ showed no significant differences from controls, these animals can be considered as truly healthy. In contrast, the animals with $\gamma$-glutamyltransferase higher than $112 \mathrm{U} / \mathrm{l}$ showed increases of the same parameters as group B animals, except for alanine aminotransferase which is known to be a poorly sensitive marker of liver damage in sheep (18). Nevertheless, the toxic effects were less severe than in clinically ill animals, especially for cholestasis, as shown by very significantly smaller increases of $\gamma$-glutamyltransferase, cholesterol, bilirubin $(p<0.001)$ and alkaline phosphatases $(p<0.003)$. In facial eczema, photosensitization results from accumulation in the skin of phylloerythrin, a photoactive metabolite of chlorophyll normally excreted in bile (22); a less intense cholestasis could account for the absence of photosensitization in group $\mathrm{C}$ animals with $\gamma$-glutamyltransferase higher than $112 \mathrm{U} / 1$.

Thus, animals of groups B and C, which were exposed to the same risks, as they grazed the same pastures, showed three very different responses; this heterogeneity cannot probably be accounted for by one single factor: it could result from individual resistance or sensitivity of sheep (23), or from a different ingestion of toxins resulting from the repartition of the fungus on the pasture, from the toxinogenesis of the strains and/or from the quantity of spores ingested by each animal $(24,25)$.

The evolution of serum biochemistry with time could not be very accurately determined because many animals died or were slaughtered. Thus surviving animals are not representative of the whole flock.

\section{References}

1. Atherton, L. G., Brewwer, D. \& Taylor, A. (1974) in $M y-$ cotoxins (Purchase I.F. M., ed.) pp. 29-68, Elsevier, Amsterdam.

2. Bézille, P., Braun, J. P. \& Le Bars, J. (1984) Rec. Méd. Vét. $160,339-347$.

3. Towers, N. R. (1978) N. Z. Vet. J. 26, 142-145.

4. Done, J., Mortimer, P. H. \& Taylor, A. (1960) Res. Vet. Sci. $1,76-83$.

5. Done, J., Mortimer, P. H. \& Taylor, A. (1962) Res. Vet. Sci. 3, 161-171.

6. Leaver, D. D. (1968) Res. Vet. Sci. 9, 265-273.

7. Peters, J. A. \& Mortimer, P. H. (1970) Res. Vet. Sci. 11, $183-188$.

8. Towers, N. R. \& Stratton, G. G. (1978) N. Z. Vet. J. 26, 109-112.

9. Ford, E. J. H. (1965) J. Comp. Pathol. 75, 299-308.
In survivors tested for 200 days, the decrease of cholestasis, cytolysis and liver insufficiency (based on the levels of $\gamma$-glutamyltransferase and cholesterol, lactate dehydrogenase, and glucose, respectively) did not occur until day 200 following the first symptoms. Even at this date, $\gamma$-glutamyltransferase and lactate dehydrogenase activities indicated the persistence of some cholestasis or induction associated with a moderate cytolysis.

In the group of animals observed one year after the outburst of the disease, a similar but more moderate increase of $\gamma$-glutamyltransferase was observed; as in the case of the decreased serum glucose, this could result from an altered alimentary supply. The elevation of total proteins could be the consequence of a chronic inflammatory process; it was also observed in the five ewes observed for 200 days (mean $=75 \mathrm{~g} / \mathrm{l}$ ) but it was not statistically significant.

Although it has been reported that serum $\gamma$-glutamyltransferase is correlated with the severity of experimental liver damage by sporidesmins (8), our observation, one year after the outbreak of the disease, of very high serum $\gamma$-glutamyltransferase levels in sheep having an excellent health status casts some doubts on the value of this parameter for predicting the economical future of animals. Thus, serum biochemistry cannot be used for prognostic purposes, whereas measurement of serum $\gamma$-glutamyltransferase levels is the best criterion for detecting the liver lesions of facial eczema, even in apparently healthy animals.

\section{Acknowledgement}

This study was conducted under contract No. 74140 , by the DGER (Direction Générale des Etudes et de la Recherche) of the Ministère de l'Agriculture, Paris, France and with the cooperation of the Département des Productions animales of the Veterinary School of Toulouse.

10. Mortimer, P. H. (1962) Res. Vet. Sci. 3, 269-286.

11. di Menna, M. E., Mortimer, P. H. \& White, E. P. (1977) In: Mycotoxic fungi, mycotoxins, mycotoxicosis. An encyclopedic handbook, Volume I: Mycotoxic fungi and chemistry of mycotoxins. (Wyllie, T. D. \& Morehouse, L. G., eds.) pp. 99-103, Marcel Dekker, New York.

12. White, E. P., Mortimer, P. H. \& di Menna, M. E. (1977) In: Mycotoxic fungi, mycotoxins, mycotoxicosis. An encyclopedic handbook, Volume I: Mycotoxic fungi and chemistry of mycotoxins. (Wyllie, T. D. \& Morehouse, L. G., eds.) pp. 427-447, Marcel Dekker, New York.

13. Bonnefoi, M., Sauvagnac, P., Massat, F. \& Le Bars. J. (1987) Rev. Méd. Vét. 138. $991-994$.

14. Taiturier, D., Braun, J. P., Rico, A. G. \& Thouvenot, J. P. (1984) Res. Vet. Sci. 37, 129-131. 
15. Schwarz, D. (1963) Méthodes statistiques à l'usage des médecins des biologistes, Flammarion, Paris.

16. Jordan, T. W. \& Pedersen, J. S. (1986) J. Cell Sci. 85 $33-46$.

17. Jordan, T. W. \& Cordiner, S. J. (1987) Trends Pharmacol. Sci. 8, 144-149.

18. Braun, J. P., Bézille, P. \& Rico, A. G. (1986) Rep. Nutr Dév. 26, 227-243.

19. Mortimer, P. H. \& Taylor, A. (1962) Res. Vet. Sci. 3, 147160.
20. Blackshaw, C. (1978) N. Z. Vet. J. 26, 16-26.

21. Edwards, J. R., Reichards, R. B., Loeve, R. A., Harrison, M. R. \& Gwynn, R. V. R. (1983) Aust. Vet. J. 60, 157.

22. Galitzer, S. J. \& Oehme, F. W. (1978) Vet. Sci. Commun. 2, 217-230.

23. Smith, B. L., Stanbridge, T. A. \& Embling, P. P. (1980) N. Z. Vet. J. $28,35-36$.

24. di Menna, M. E. \& Bailey, J. R. (1973) N. Z. J. Agric. Rec. $16,343-351$.

25. di Menna, M. E., Campbell, J. \& Mortimer, P. H. (1970) J. Gen. Microbiol. 6, 87 $=96$.
Marc Bonnefoi
Laboratoire Associé INRA de
Toxicologie Biochimique et Métabolique Ecole Nationale Vétérinaire de Toulouse 23, chemin des capelles
F-31076 - Toulouse Cedex 